\title{
Dispute over the Applicable Scope of the Svalbard Treaty: A Chinese Lawyer's Perspective
}

\author{
Tianbao Qin*
}

The Svalbard Treaty, one of the few inter-governmental treaties in the Arctic area, has drawn global attention. Currently, the dispute focuses mainly on its scope of applicability. Different interpretations of the issue, directly affect each contracting party's interests in Svalbard, intensifying its debate. China signed the Svalbard Treaty on July 1, 1925, becoming one of its first contracting parties. China has attached great importance to non-discriminatory rights under the treaty, such as scientific research, resource exploitation, fishing, hunting and commercial activities, etc. Therefore, the final determination of the treaty's applicable scope has a profoundly direct impact on China's interests in the Arctic area. This research is to analyze the Chinese position on the Svalbard Treaty and to demonstrate the legitimacy of China's viewpoint from a treaty interpretation perspective.

\section{Keywords}

Svalbard Treaty, Arctic Ocean, Applicable Scope, Treaty Interpretation, Intertemporal Law, terra nullius, China

* Luojia Professor of Law, Research Institute of Environmental Law ("RIEL"), Collaborative Innovation Center of Territorial Sovereignty and Maritime Rights of Wuhan University, China. LL.B./LL.M.(Wuhan), Dr. iur. (Wuhan \& Frankfurt). ORCID: http://orcid.org/0000-0003-4932-9213. This paper was supported by research projects, "Legal Issues on Biodiversity beyond National Jurisdiction" commissioned by China Institute for Marine Affairs, and "Law and Practice of Establishment and Management of Protected Areas in High Seas" commissioned by China Association of Marine Affairs. The author thanks Mr. Qingchuan Zhang, LLM candidate at RIEL for his assistance in writing of the paper. Views and errors expressed in this paper, if any, are solely the author's responsibility and do not represent the official position of the P.R. China. The author may be contacted at: fxyqtb@whu.edu.cn / Address: Luojiashan, Wuchang District, Wuhan, Hubei Province, 430072, China. DOI: http://dx.doi.org/10.14330/jeail.2015.8.1.07 


\section{Introduction}

Svalbard is located in the Arctic Ocean, between the Barents Sea and the Greenland Sea, including the islands of Spitsbergen, North-East Land, Edge, Barents Islands and Bear Island and rocks appertaining thereto, with an area of more than 62,000 square kilometers.

Figure 1: The Svalbard Islands ${ }^{1}$

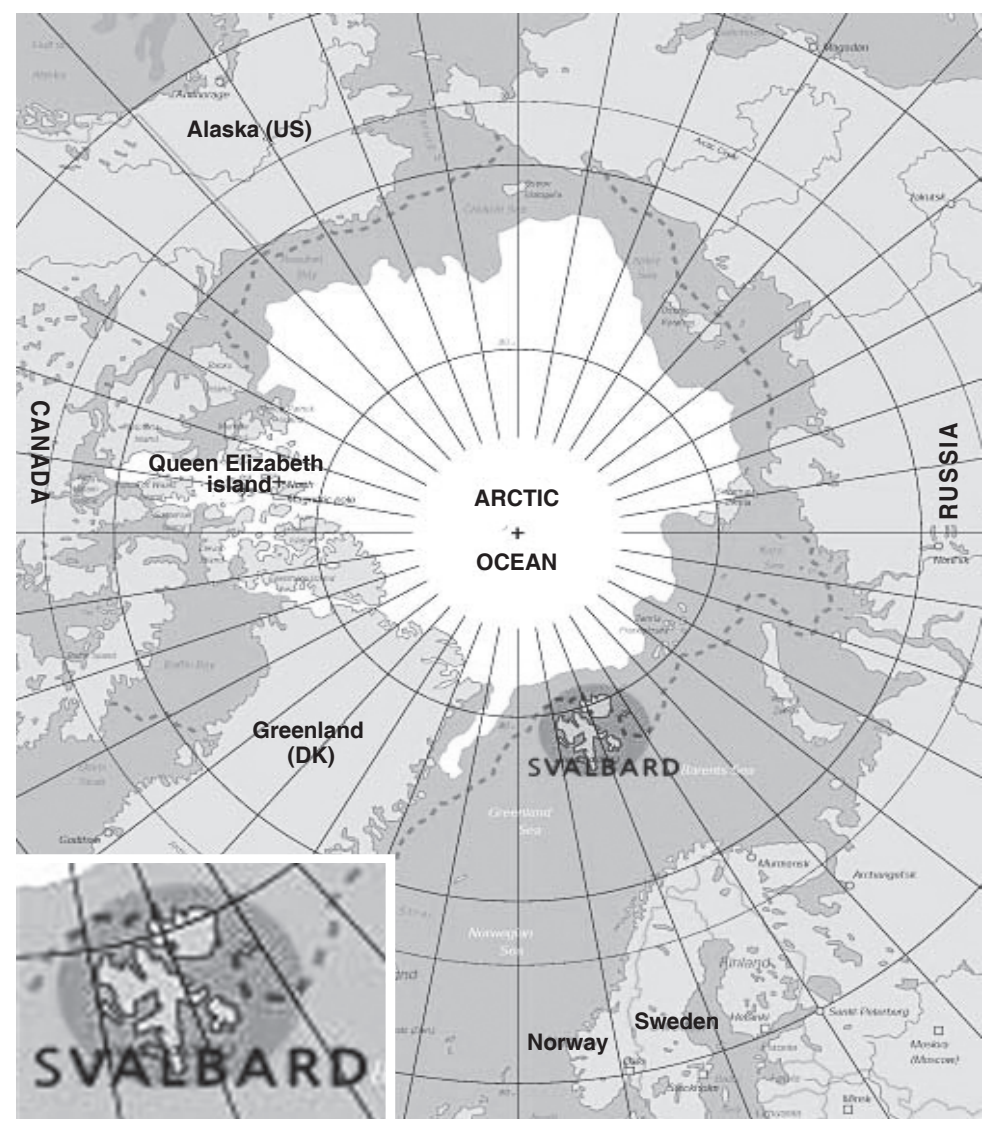

1 Norwegian Polar Institute, Maps, available at http://www.npolar.no/en/services/maps (last visited on May 9, 2015). 
On February 9, 1920, the Treaty concerning the Archipelago of Spitsbergen (hereinafter Svalbard Treaty) ${ }^{2}$ was signed jointly by the UK, the US, Denmark, Norway, Sweden, France, Italy, the Netherlands, Japan and other nine countries in Paris. ${ }^{3}$ This Treaty has changed the legal status of the terra nullius in Svalbard by giving Norway sovereignty purporting to be "Desirous, while recognizing the sovereignty of Norway over the Archipelago of Spitsbergen, including Bear Island, of seeing these territories provided with an equitable regime, in order to assure their development and peaceful utilization."

Due to global warming, the Arctic area is changing from a permanently frozen area to that of a seasonally ice-free zone. This change has caused global concern for the interests in many aspects of the Arctic area, such as the ownership of territory, exploitation of resources, waterway access, etc. ${ }^{5}$ The Svalbard Treaty, one of the few inter-governmental treaties in the Arctic area, has drawn global attention. Currently, the dispute focuses mainly on its scope of applicability. Different interpretations of the issue, directly affect each contracting party's interests in Svalbard, intensifying its debate.

China signed the Svalbard Treaty on July 1, 1925, becoming one of its first contracting parties. ${ }^{6}$ Today, under the conditions that the Arctic territories are all vested in the Surround-Arctic Nations, the Svalbard Treaty not only serves as an important connecting factor between China and the Arctic matters, but also establishes a critical channel for China to participate in discussions of Arctic issues. Meanwhile, as an important part of its Arctic interests, China has attached great importance to non-discriminatory rights under the treaty, such as scientific research,

2 Since its discovery by Barents in 1596, the archipelago had been named as 'Spitsbergen.' In 1925, Norway obtained sovereignty of the islands and made the archipelago and Bear Island collectively referred to as 'Svalbard.' So, Treaty concerning the Archipelago of Spitsbergen is also known as The Svalbard Treaty. For details, see The Governor of Svalbard, available at http://www.sysselmannen.no/en/Toppmeny/About-Svalbard/Laws-and-regulations/SvalbardTreaty (last visited on May 11, 2015).

3 The treaty was entered into force on August 14, 1925. See L. Numminen, A History and Functioning of the Spitsbergen Treaty, in The Spitsbergen Treaty: Multilateral Governance in the Arctic 8 (D. Wallis MeP \& S. Arnold eds. 2011), available at http://dianawallis.org.uk/en/document/spitsbergen-treaty-booklet.pdf(last visited Apr. 27, 2015).

4 See Treaty concerning the Archipelago of Spitsbergen, and Protocol (Aug. 14, 1925), Australian Treaty Series 1925 No.10, available at http://www.austlii.edu.au/au/other/dfat/treaties/1925/10.html (last visited May 11, 2015). [hereinafter Svalbard Treaty].

5 Fanghua Lu, The Svalbard Treaty and China’s Arctic Rights [《斯瓦尔巴德条约》与我国的北极权益] 88 (2013).

6 See The Rights of Chinese People to Free to Access to Svalbard: Due to the Signing of the Svalbard Treaty by the Beiyang Government [拜北洋政府签《斯瓦尔巴条约》之赐, 中国人可自由进出挪威属地], available at http://qnck.cyol.com/content/2009-12/15/content_2984452.htm (last visited on May 10, 2015). <available only in Chinese> 
resource exploitation, fishing, hunting and commercial activities, etc. Therefore, the final determination of the treaty's applicable scope has a profoundly direct impact on China's interests in the Arctic area.

The primary purpose of this research is to analyze the Chinese position on the Svalbard Treaty and to demonstrate the legitimacy of China's viewpoint from a treaty interpretation perspective. This paper is composed of five parts including short Introduction and Conclusion. Part two will show the relationship between China and the Svalbard Treaty. Parts three and four will examine the legitimacy of China's point over the Svalbard Treaty from different aspects. Part five will give some conclusions.

\section{China's Arctic Interests and the Dispute over the Svalbard Treaty}

\section{A. China's Arctic Interests}

Since the Chinese government has not published the Arctic strategies or relevant policies, ${ }^{7}$ its Arctic interests in the official position are not clear. However, considering a series of actions of the Chinese government in the Arctic area, relevant academic researches and comments by domestic and foreign media, China's Arctic interests are supposed to mainly focus on the following three areas: scientific research interests, political interests and economic interests.

\section{Scientific Research Interests}

Scientific research is a concerning are in the Arctic area. The four existing Arcticrelated official organizations of China - the Polar Research Institute of China, Chinese Arctic and Antarctic Administration, Chinese National Arctic and Antarctic Data Center, and China-Nordic Arctic Research Center. The Polar Research Institute of China, Iceland Research Center and some other Arctic research institutes from Iceland, Denmark, Finland and Sweden signed the Cooperation Agreement on the China-Nordic Arctic Research Center in Shanghai on December 10, 2013 formally

7 See The Arctic Exploitation: Does China Really Get Ready? [北极开发, 中国真的来了吗?], available at http:// paper.people.com.cn/rmwz/html/2012-09/01/content_1113745.htm?div=-1 (last visited on Apr. 27, 2015). <available only in Chinese> In 2009, as the Assistant Foreign Minister, Hu Zhengyue clearly claimed that "China has no Arctic strategy yet." Since then, Chinese officials have addressed no further statement. 
marking the inauguration of China-Nordic Arctic Research Center. ${ }^{8}$ China's 'Snow Dragon' scientific research ship departing from Shanghai Pudong went to the North Pole for its sixth Arctic scientific expedition on July 11, 2014. ${ }^{9}$

China's scientific research interests mainly include two aspects. One is to strengthen the understanding of the Arctic environment, including the hydrology, meteorology, marine geology, geo-physics and marine biology of the Arctic Ocean, the distribution and variation of ecology, marine chemistry, ice and other environmental factors. ${ }^{10}$ The other is to deepen the understanding of the rapid changes in the Arctic environment and its impact on global climate change. ${ }^{11}$ The changes in the Arctic environment, especially temperature, will adversely affect China's overall ecosystem, food security and industrial development. ${ }^{12}$ In addition, because China's highly industrialized cities are mostly located in the eastern coastal areas, the sea-level rise caused by melting glaciers poses a huge threat to China's economic security.

\section{Political Interests}

Politics has always been a sensitive topic in international exchange and cooperation. That is because the relationship pattern determined by it is often the foundation to realize the demands of other aspects, so each country projects a very cautious attitude towards such related affairs. China has no territory in the Arctic Circle, so participation in the political affairs of the Arctic may have insufficient legitimacy. With rapid globalization, however various questions arising from different parts of the world would have an extensive impact on many countries often beyond the scope of a territory. At the same time, these cross-regional and global problems cannot be solved by unilaterally, but requires a number of countries for global cooperation. Currently, the international community primarily concern about the related topics of environmental protection and climate change. ${ }^{13}$ China is also

8 See China-Nordic Arctic Research Center Officially Opened and Held Its First Member Meeting [中国-北欧北极研 究中心成立 召开首次成员机构会议], available at http://www.gov.cn/gzdt/2013-12/12/content_2546677.htm (last visited on Apr. 15, 2015). <available only in Chinese>

9 See The Chinese Arctic and Antarctic Administration, The "Snow Dragon" Scientific Research Ship Went to the North Pole for the Sixth Arctic Scientific Expedition [ “雪龙” 出征六探北极], available at http://www.chinare. gov.cn/caa/gb_news.php?id=1465\&modid=01002 (last visited on Apr. 15, 2015). <available only in Chinese>

10 Id.

11 Id.

12 See National Development and Reform Commission of PRC, China's National Climate Change Programme, at 16-9,

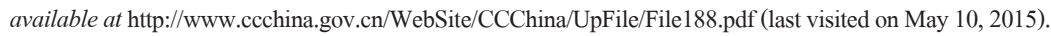

13 See UN, Promote Sustainable Development, available at http://www.un.org/en/sections/what-we-do/promotesustainable-development/index.html; International Years, available at http:/www.un.org/en/sections/observances/ 
actively involved this process, seeking for extensive cooperation with other countries to explore solutions to these problems. But this does not mean that China has no relevant interests in the Arctic are in a political sense. China defines herself as a "Nation near the Arctic." It means that as her geographical location is very close to the Arctic, those affairs will have a significant influence on China. Hence, China is entitled to participate in such Arctic affairs. ${ }^{14}$

In the political field, China's national concern mainly includes security interests in the Arctic affairs. In particular, the Arctic area is located between the world's three major strategic areas - North America, Europe and East Asia. The North Pole is the minimum point distant from the core countries of the three strategic areas; it can be said that those who can control the North Pole will effectively 'control' these three major strategic areas. ${ }^{15}$ As one of the core countries in East Asia, China is concerned about the Arctic area in order to guarantee her security interests. From the perspective of non-traditional security, the Arctic area has a significant impact on the global environment, resource exploitation and channel utilization. Therefore, it has a profound impact on Chinese environmental and economic security. Since it has an important impact on many aspects of the interests of the world, each country including China is willing to participate in Arctic affairs. ${ }^{16}$

It is acknowledged that the governance rules and framework of the Arctic area is still in controversy and its governance system needs to be improved. The globalization of Arctic problems needs extensive participation of the entire world community. Only with the full participation of the major international powers, including China, Korea, Japan, Australia and some other non-Arctic countries, can Arctic governance be reasonable and effective.

\section{Economic Interests}

Since the sea ice began melting, the Artic area can be gradually exploited and utilized. In this course, the huge economic benefits may also attract attention of

international-years/index.html (all last visited Apr. 29, 2015).

14 Sisi Liu, The Proposal of the Mechanism of "Near the Arctic” and China's Participation in the Arctic [ “近北极 机制” 的提出与中国参与北极], 10 Soc. ScI. [社会科学] 30 (2012). < available only in Chinese>

15 Hui Wu, The International Law Analysis of “Battle for the Arctic” [ “北极争夺战” 的国际法分析], J. U. INT'L REL. [国际关系学院学报] 37 (2007). <available only in Chinese>

16 Jian Yang, China is a Constructive Participant in the Arctic Affairs [中国是北极事务的建设性参与者], GuANG Ming DAILY [光明日报], Apr. 1, 2013, available at http://epaper.gmw.cn/gmrb/htm1/2013-04/01/nw.D110000gmrb_ 20130401_1-08.htm < available only in Chinese> See also Kuncheng Fu, Arctic Affairs Can Not Do without China's Participation [傅崐成: 北极事务少不了中国参与], available at http://opinion.huanqiu.com/opinion_world/ 201304/3792116.html < available only in Chinese > (all last visited on May 3, 2015). 
more countries. As one of the world's major economies, China has her economic interests in the Arctic area encompassing resource and trade interests. In particular, energy-oil and gas are the target resource in the area. In 2008, the US Geological Survey carried out the Circum-Arctic Resource Appraisal project. According to the data of the project, the Arctic area has as many as 90 billion barrels of undiscovered oil reserves, accounting for 13 percent of global undiscovered reserves; 166,900 billion cubic feet of natural gas reserves, equivalent to Russia's all known reserves, accounting for 30 percent of the world's undiscovered reserves. ${ }^{17}$ It is also claimed that most of the Arctic continent may be unexplored and hold the remaining oil. ${ }^{18}$ Recently, as China's energy consumption has increased sharply and the growth rate of domestic energy production is very limited, the demand of import has been rapidly rising. As for oil, e.g., in September 2013, China already became the world's top oil importer surpassing the US. ${ }^{19}$ Consequently, the rich resources of the Arctic area have great appeal to China.

In the trade aspect, because Arctic sea ice is melting the commercial use of Arctic waterways would become possible. Arctic waterways include the Northwest Passage and the Northeast Passage. Once realizing commercial navigation, it will be the most convenient channel connecting North America, Northern Europe and China. ${ }^{20}$ If passing through Arctic waterways, China will greatly reduce the cost of foreign trade. In addition, economic connection between China and the Arctic countries is very close, constituting another important aspect of China's trade interests in the Arctic area. E.g., China and Iceland signed a free trade agreement in April 2013. Among them, in the terms of goods trade, the zero-tariff products between the two countries are close to 96 percent according to the tariff amount and close to 100 percent according to the trade amount. ${ }^{21}$

\section{B. China's Relevances to the Arctic Dispute}

China's threefold interests in the Arctic area are closely inter-related. Currently, they

17 See US Geological Survey, Circum-Arctic Resource Appraisal: Estimates of Undiscovered Oil and Gas North of the Arctic Circle, available at http://pubs.usgs.gov/fs/2008/3049/fs2008-3049.pdf (last visited on May 3, 2015).

18 Id.

19 R. Gold, Fracking Gives U.S. Energy Boom Plenty of Room to Run, WaLL St. J., Sept. 14, 2014, available at http:// www.wsj.com/articles/fracking-gives-u-s-energy-boom-plenty-of-room-to-run-1410728682 (last visited on Apr. 19, 2015).

20 Supra note 14 , at 27-8.

21 See Iceland's Parliament Authorizes the Government to Ratify the Free Trade Agreement with China [冰岛议会 授权政府批准中冰自由贸易协定], available at http://www.gov.cn/jrzg/2014-01/30/content_2578550.htm (last visited on Apr. 14, 2015). <available only in Chinese> 
have proved to be more valuable to China. The Svalbard Treaty is one of the few intergovernmental treaties with international flavor in the Arctic area. In particular, as an important connection point between China and the Arctic, the debate of its application scope will have an important impact on the Arctic interests of China.

\section{The Dispute of Applicable Scope}

Under the 1982 United Nations Convention on the Law of Sea ("UNCLOS") and customary international law, the exclusive economic zone ("EEZ") and the continental shelf reflect significant development of marine technology. ${ }^{22}$ It should be noted that the establishment of the EEZ and the continental shelf regime greatly expands coastal States' maritime rights under the UNCLOS and customary law of the sea giving them exclusive rights to resource exploitation in these areas. It confers huge economic benefits on the coastal States. ${ }^{23}$ The Svalbard Treaty which was signed 62 years earlier than the UNCLOS has obvious difficulties in adopting this new marine division rule. Therefore, it produced a gray area on the applicable scope of the Svalbard Treaty, especially on whether the treaty can apply to EEZ and the continental shelf around Svalbard. Also, the contention between contracting parties to the exclusive rights of EEZ ${ }^{24}$ and the continental shelf constitutes the dispute of the scope of applicability of the Svalbard Treaty.

In December 1976, the Act relating to the Economic Zone of Norway was promulgated by the Norwegian government. According to the Act, Norway has the authority to establish 200 nautical miles ("nm”) EEZ, which also includes Svalbard waters. ${ }^{25}$ In 1977, Norway established a 200 nm Fishery Protection Zone in Svalbard waters. ${ }^{26}$ It declared that the non-discriminatory principle of the Fishery Protection

22 Huirong Liu \& Xinyuan Zhang, The Research on the Applicable Scope of the Svalbard Treaty: From the Perspective of UNCLOS [斯瓦尔巴群岛的法律适用问题研究-以《联合国海洋法公约》为视角], J. OCEAN U. CHINA [中国海 洋大学学报] 2 (2009). < available only in Chinese>

23 Within the exclusive economic zone, a coastal state does not have sovereignty, but sovereign rights over the natural resources both in and on the seabed and in the ocean areas above. This means that the coastal State has the sovereign right to exploit, preserve and manage resources such as oil, gas and fish.

24 Because of the opposition from other contracting parties, Norway had established a fishery protection zone which owns a similar nature of exclusive economic zone around Svalbard instead of establishing an exclusive economic zone directly. Based on this, this paper will use "fishery protection zone" referring to the exclusive economic zone. It should be noted that, the conclusion of this paper is equally applicable to the exclusive economic zone around Svalbard if Norway decided to establish one.

25 Act No. 91 of 17 December 1976 relating to the Economic Zone of Norway, q 1, available at http://www.un.org/ depts/los/LEGISLATIONANDTREATIES/PDFFILES/NOR_1976_Act.pdf (last visited on Apr. 26, 2015).

26 Norwegian Fisheries Administration, The Norwegian Exclusive Economic Zone, available at http://www.fisheries. no/resource_management/Area_management/economic_zone/\#.U-9ibrLs64Q (last visited on May 10, 2015). 
Zones embodied the 'equitable regime' established by the Svalbard Treaty. ${ }^{27}$ Norway has taken a more eclectic principle for the reason that:

\begin{abstract}
Since the applicable scope of the Svalbard Treaty remains controversial, if Norway directly announced the establishment of exclusive economic zone in Svalbard waters will inevitably meet direct interest conflicts from other contracting parties ${ }^{28}$ - Spain, Iceland has once questioned about the right of Norway to exercise jurisdiction in waters surrounding Svalbard and has vowed to resort to the International Court of Justice ${ }^{29}$ Russia has also explicitly declared that if Norway claims 200 nautical miles exclusive economic zone, it would also take the same measures to protect its interests in Svalbard. ${ }^{30}$
\end{abstract}

While Norway takes the compromised policy of setting up a fishing protection zone, there is no rejection of an exclusive right to develop resources in the fishery protection zone and the continental shelf around Svalbard. As the dispute over the applicable scope of the Svalbard Treaty has never stopped, three main views are gradually formed. The first view holds that the Svalbard Treaty does not apply to the fishery protection zone and the continental shelf ${ }^{31}$ around Svalbard, so that Norway should own unlimited jurisdiction in these two areas. This view is mainly taken by Norway, which claims that the Svalbard Treaty is only applicable to the territory, inland waters and territorial seas; Norway is not restricted by the Svalbard Treaty and has exclusive rights on the fishery protection zone and the continental shelf around Svalbard according to the provisions of the UNCLOS. ${ }^{32}$

The second view denies Norway's right of setting fishery protection zone around Svalbard and of claiming right on its continental shelf. Russia, a representative country taking the view, believes that Norway has the right to neither set fishery

27 E. Molenaar, Fisheries Regulation in the Maritime Zones of Svalbard, InT'L J. MARINE \& CoAStal L. 14-5 (2012).

28 Huirong Liu \& Yue Dong, Legal Issues in the Arctic: From Perspectives of the Law of the Sea [海洋法视角下 的北极法律问题研究] 116 (2012). <available only in Chinese>

29 Id. at 3.

30 Id.

31 Norway holds that Svalbard does not generate a continental shelf and it is a continuous continental shelf from the mainland. But the application materials of continental shelf beyond $200 \mathrm{~nm}$ submitted by Norway in 2006 to the Commission on the Limits of the Continental Shelf included the northern outer limits of Svalbard's continental shelf. These claims of Norway are all aimed at expanding her jurisdiction in the Arctic. See Liu \& Dong, supra note 28, at 117.

32 C. Fleischer, Le régime d'exploitation du Spitsberg (Svalbard), 24 AnNuaIRE FRANÇAIS DE Droit IntERnATIONAL, 275-300 (1978), available at $\mathrm{http} / / / \mathrm{www}$.persee.fr/web/revues/home/prescript/article/afdi_0066-3085_1978_num_24_1_2097 (last visited on May 7, 2015). <available only in French> See also S. Wolf, Svalbard's Maritime Zones, their Status under International Law and Current and Future Disputes Scenarios, SWP BERLIN, Jan. 2013, at 15. 
protection zone in waters around Svalbard, nor claim rights to the continental shelf. ${ }^{33}$ Spain partly supports this view, too. Although Spain criticizes Norway's mandatory policy in fishery protection zone, it has no objection to Norway's right of setting fishery protection zone around Svalbard. ${ }^{34}$

The third view is a compromised one. It advocates the Svalbard Treaty's applicability to the fishery protection zone and the continental shelf of Svalbard, other contracting parties (particularly referring to contracting parties except Norway in this paper) shall share a non-discriminatory right on resource development in them. This view admits that Norway has full sovereignty of Svalbard and approves Norway's jurisdiction on the fishery protection zone and the continental shelf around Svalbard. However, it simultaneously advocates the applicability of the Svalbard Treaty, especially the provisions on non-discriminatory rights, to the fishery protection zone and continental shelf. ${ }^{35}$ This view, taken by the UK, the Netherlands and Denmark is the mainstream position of the international community. ${ }^{36}$

It is to be noted that some countries, especially the US, France and Germany, have reserved rights they may have under the Svalbard Treaty, thereby keeping the issue under review. ${ }^{37}$

\section{Effect of Three Views to China's Arctic Interests}

These three viewpoints encompass the mainstream view of the Svalbard Treaty's scope of application in the contemporary international community and have its own advocates. However, as previously mentioned, the essence of the dispute is the competition of rights to exploit resources in the fisheries protection zone and the continental shelf of the Svalbard Archipelago. Among these three viewpoints, the second and third viewpoints are essentially the same. Although they have maintained different positions on the Norwegian jurisdiction over the fisheries protection zone and the continental shelf of the Svalbard Archipelago, they all advocate that the Svalbard Treaty can be applied to the fisheries protection zone and the continental shelf of the Svalbard Archipelago, in that they have rights to a fair share of the exclusive rights of resource exploitation, which are regulated by the UNCLOS. On the contrary, according to the first viewpoint, Norway has rights

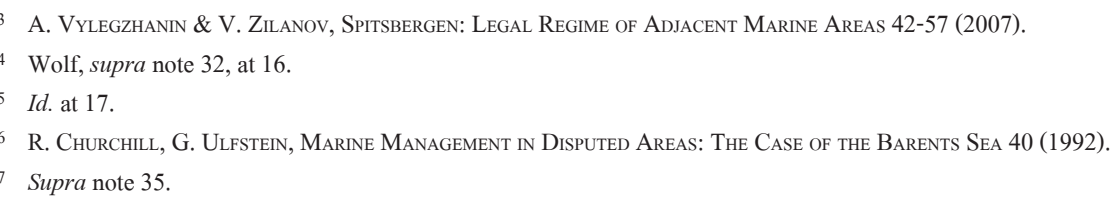


to exploit resources in the fisheries protection zone and the continental shelf of the Svalbard Archipelago. If Norwegian rights are exclusive, so other countries has nothing to share. ${ }^{38}$

China's formation of the Arctic strategy ${ }^{39}$ reflects not only her 'peaceful rise,' but also willingness to adjust to the existing Arctic governance model. ${ }^{40}$ But this intention is faced with enormous resistance from circumpolar countries. After Xi Jinping came to power in March 2013, he abandoned the Deng Xiaoping-era doctrine of "tao guang yang hui" (蹈光养晦) ${ }^{41}$ and started actively working for external relations, which makes some countries hold a more cautious attitude towards China's rise. Such attitude is also reflected in the Arctic affairs. Some countries taking advantage of the Arctic exploitation worry that China's inclusion will break the existing interest distribution pattern, thereby reducing their Arctic stakes. Take the example of China's application for official observer status in the Arctic Council. It took seven years to get through. ${ }^{42}$

To eliminate the resistance from circumpolar countries, China needs to fully demonstrate its 'peaceful rise' intention and reduce other countries' concerns by a more explicit Arctic strategy. On the other hand, China also needs to legitimize the basis for participating in the Arctic affairs actively, strengthening its substantial connection with the Arctic. From this perspective, these two viewpoints of the Svalbard Treaty's application scope will have a significant impact on China's participation in the Arctic affairs. The more actively China participates in the Artic affairs, the more she would have right to the Svalbard Archipelago.

38 According to the Norwegian point, the Svalbard Treaty does not apply to the fishery protection zone and the continental shelf around Svalbard and then Norway has a full right of the UNCLOS provisions on the exclusive economic zone. See supra note 32.

39 S. Rainwater, Race to the North: China's Arctic Strategy and Its Implications, 66 NAval War College Rev. 78 (2013).

40 Id. at 74. For details on the China's new external strategy, see Xi Jinping: New Thinking about China's Internal and Diplomatic affairs [习近平: 内政外交新思路], XINHUANET, Apr. 5, 2013, available at http://news.xinhuanet.com/ politics/2013-04/05/c_115274684_2.htm (last visited on Apr. 20, 2015). <available only in Chinese>

41 It means to avoid openly demonstrating one's capability and instead keeping a low profile. See M. Lanteigne, China's Emerging Arctic Strategies: Economics and Institutions, available at http://ams.hi.is/wp-content/uploads/2014/11/Chi nasEmergingArcticStrategiesPDF_FIX2.pdf; D. Paal, Contradictions in China's Foreign Policy, Carnegie Endowment for International Peace, Dec. 13, 2013, available at http://carnegieendowment.org/2013/12/13/contradictions-in-chinas-foreign-policy/gw4w (all last visited on Apr. 20, 2015).

42 See It Has Taken China 7 Years to Become the Official Observer Status in the Arctic Council [中国成为北极理事会 正式观察员 为此等了七年], available at http://world.huanqiu.com/exclusive/2013-05/3937750.html (last visited on Apr. 23, 2015). <available only in Chinese> 


\section{The Point of Contention}

The main contention of the dispute exists between the first view and the other two. In order to make this issue clear, further analysis should be made from the aspects of applicable provisions. It would change their connotations and claims of the contending parties.

The Svalbard Treaty does not provide a general provision on its applicable scope. Instead, it describes its applicable scope separately in specific provisions in the setting forth of non-discrimination rights of other contracting parties. ${ }^{43}$ These specific provisions can conclude that the Svalbard Treaty's applicable scope includes all the islands and its appertaining rocks specified in Article 1 and in their territorial waters. Article 1 marks out a rectangle zone there, boundary of which was defined by longitude $\left(10^{\circ} \sim 35^{\circ}\right.$ E. Longitudes) and latitude $\left(74^{\circ} \sim 81^{\circ} \mathrm{N}\right.$. Latitude). ${ }^{44}$ This rectangle zone is referred to as the Svalbard box.

Figure 2: The Svalbard Box ${ }^{45}$

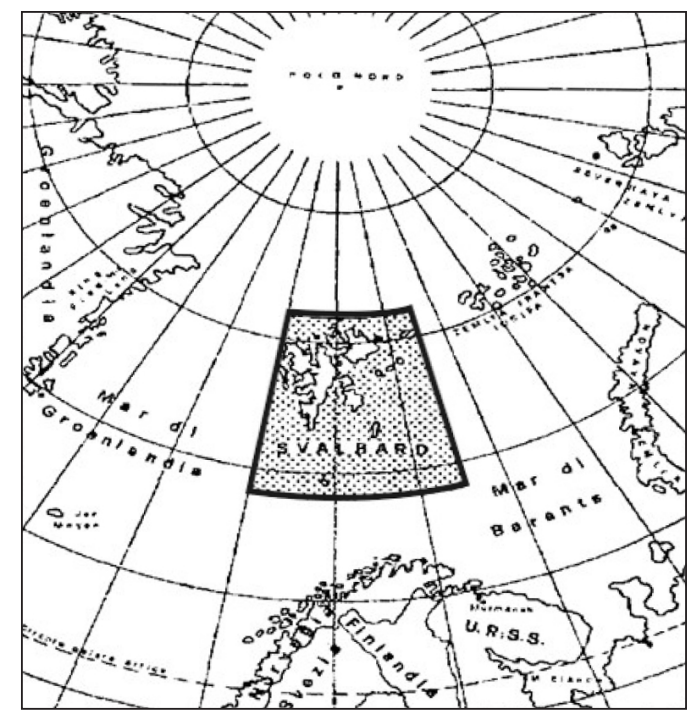

43 Svalbard Treaty arts. 2, 3, 4, 5, 7, 8, 9 \& 10.

44 G. Ulfstein, Spitsbergen/Svalbard, $\uparrow$ 39, in Max Planck Encyclopedia of Public International Law (2012) available at http://opil.ouplaw.com/view/10.1093/law:epil/9780199231690/law-9780199231690-e1356?rskey=3B 7kQz\&result=1\&prd=EPIL (last visited on May 10, 2015).

45 I. Caracciolo, The Unresolved Controversy on the Legal Regime of Maritime Areas around the Svalbard Islands. An Interpretation of 1920 Svalbard Treaty under the Light of UNCLOS 1982, 2 DisPUTED TERritory \& Maritime SPACE, available at https://www.dur.ac.uk/ibru/conferences/sos/programme/2_april/track2_session5 (last visited on May 10, 2015). 
The territorial waters of all the islands within this zone are to abide by the treaty. The scope of the territorial waters, however, is not clearly defined by the Svalbard Treaty. Besides, before the UNCLOS came into effect, there had not been a unified width of territorial sea determined by each country. Norway then declared the width of its territorial sea as $4 \mathrm{~nm}$. Therefore, when the Svalbard Treaty became effective, its applicable scope is the islands within the Svalbard box and the $4 \mathrm{~nm}$ around them. In June 2001, Norway passed the Regulation relating to the limit of the Norwegian territorial sea around Svalbard which has clearly defined the boundary of Svalbard. According to this Regulation, Norway gave up using the Ebb baseline but started to adopt the new straight baseline. ${ }^{46}$ In 2003, Norway extended the breadth of its territorial sea to $12 \mathrm{~nm}$, including the maritime area around Svalbard. ${ }^{47}$ From then on, without disputes, the Svalbard Treaty's scope of application extended to $12 \mathrm{~nm}$ around Svalbard.

As a result, a dispute may arise on the fishery protection zone and the continental shelf, to be covered in the term 'territorial waters' in the Svalbard Treaty. From the perspective of the rights to distribution, could other contracting parties enjoy nondiscrimination rights in these two areas? In response to this question, Norway, essentially, as shown in the first view, claims that the concept of 'territorial waters' in the Svalbard Treaty has the same meaning with 'territorial sea' in the UNCLOS. ${ }^{48}$ The UNCLOS provides:

The sovereignty of a coastal State extends, beyond its land territory and internal waters and, in the case of an archipelagic State, its archipelagic waters, to an adjacent belt of sea, described as the territorial sea. ${ }^{49}$

Every State has the right to establish the breadth of its territorial sea up to a limit not exceeding 12 nautical miles, measured from baselines determined in accordance with this Convention. ${ }^{50}$

Accordingly, the Svalbard Treaty would not apply to the fishery protection zone and

$46 \mathrm{UN}$, Regulation relating to the Limit of the Norwegian Territorial Sea around Svalbard, available at http://www. un.org/depts/los/LEGISLATIONANDTREATIES/PDFFILES/DEPOSIT/nor_mzn38_2001.pdf (last visited on May 12, 2015).

47 Act of 27 June 2003, in UN Document Law of the Sea Bulletin No. 54 (2004).

48 As mentioned above, if the Svalbard Treaty does not apply to the fishery protection zone and the continental shelf around Svalbard, Norway would have a full right of the UNCLOS provisions on the exclusive economic zone.

49 UNCLOS art. 2(1).

$50 \quad$ Id. art. 3. 
the continental shelf. Although the concept of 'territorial waters' is in evolution, as displayed in both lexical meaning and the rights of contracting parties prescribed in the Svalbard Treaty, the concept of fishery protection zone and the continental shelf refers to special rights areas derived from the territorial sea.

The core of the dispute would be the comprehension of 'territorial waters' in the Svalbard Treaty relating to treaty interpretation. There are two ways of treaty interpretation. One is the 'objective interpretation,' focusing on the inherent meaning of law; the other is the 'subjective interpretation' or 'voluntarism,' exploring legislators' psychological intentions in history. ${ }^{51}$ These perspectives can be applied when interpreting the meaning of 'territorial waters' in the Svalbard Treaty. Karl Larenz held:

The ultimate goal of legal interpretation cannot be anything but to explore the standard significance of law under legal orders (the law's normative significance nowadays). It can only be defined when taking legislators' intentions and their specific thought into account instead of ignoring them. ${ }^{52}$

The goal of treaty interpretation is to give considerations to the rational composition in both the objective and subjective theory. The significance of 'territorial waters' in the Svalbard Treaty should be also analyzed from this comprehensive perspective.

\section{Legal Questions}

\section{A. Intertemporal Law}

Etymologically speaking, inter-temporal law is the law of resolution of conflicts in time of laws. ${ }^{53}$ It was formulated by Judge Huber in Island of Palmas case (Netherlands v. U.S.) as follows:

51 K. Larenz: Methodenlehre der Rechtswissenschaft 316 (1995). <available only in German>

52 Id. at 318 .

53 From the etymological point of view, 'inter-temporal' can be traced back to Latin 'tempus,' 'temporal' and 'inter.' See Yuanlong Huang, The Concept of Intertemporal Law in International Law [国际法上的时际法概 念], 2 Foreign L. Translation \& Rev. [外国法译评] 74-5 (2000). < available only in Chinese> Currently, intertemporal law does not have a general definition and relevant literature generally illustrates its nature by clarifying its application. See M. Kotzur, Intertemporal Law, 6 The Max Planck Encyclopedia of Public International Law 278 (R. Wolfrum ed., 2012). 
Both Parties are also agreed that a juridical fact must be appreciated in the light of the law contemporary with it, and not of the law in force at the time when a dispute in regard to it arises or falls to be settled. ${ }^{54}$

Huber also emphasized the inter-temporal law results in another rule:

As regards the question which of different legal systems prevailing at successive periods is to be applied in a particular case (the so-called intertemporal law), a distinction must be made between the creation of rights and the existence of rights. The same principle which subjects the act creative of a right to the law in force at the time the right arises, demands that the existence of the right, in other words its continued manifestation, shall follow the conditions required by the evolution of law. ${ }^{55}$

According to the rights acquired when the facts occurred, its continuing existence must be in line with the evolution of international law demand thereafter. Following this viewpoint, it should be in this evolutionary way that the interpretation of the words in the treaty for establishing rights, must be made. This paper defines the method as 'evolutionary interpretation.'

In the Aegean Sea Continental Shelf case (Greece v. Turkey) of 1978, the International Court of Justice ("ICJ") explicitly established two conditions for applicable to evolutionary interpretation for the first time. It pointed out that the reason for the evolutionary interpretation of the term, 'territorial status' in the Peaceful Settlement of International Disputes General Act of 1928, is based on the term's 'general' meaning and the treaty's 'continuing duration. ${ }^{56}$ Namely, the terms should be general and the treaty unlimited.

\section{B. Evolutionary Interpretation}

Then, the questions remain as to (1) whether the term 'territorial waters' in the Svalbard Treaty has generality? and (2) whether the Svalbard Treaty has 'indefinite' nature? The answers to both questions are positive. The UN International Law Commission concluded that contracting parties would aim at using the evolution interpretation as long as the treaty uses technical, economical or legal concepts

54 Island of Palmas (Neth. v. U.S.), Award of 4 April 1928, 2 UNRIAA, at 845.

55 Id.

56 Aegean Sea Continental Shelf (Greece v. Turk.), Judgment, 1978 ICJ, 77 (Dec. 19), available at http://www.icjcij.org/docket/index.php?sum=327\&p1=3\&p2=3\&case=62\&p3=5 (last visited on May 9, 2015). 
or expresses these concepts with general terms. ${ }^{57}$ Referring to this criterion, the 'territorial waters' here is obviously a general concept. The 'indefinite' nature of the Svalbard Treaty is even more reasonable. On the one hand, the Svalbard Treaty does not have a certain termination time, which makes it a continuing treaty. On the other, there exists open terms, such as 'sovereignty,' 58 'land territory,' 'territorial waters,' 'fishing rights,' 'hunting rights,' 59 and 'access rights,' 'industrial activities,' 'mining activities,' 'trading activities. ${ }^{\prime 60}$ Meanwhile, the Svalbard Treaty has definite expectation of future cooperation. Article 2 has synoptically stipulated that Norway should endow other contracting parties with non-discrimination rights, and then stipulates the rights to access, hunting, open mineral, commerce, and the scientific research precisely. ${ }^{61}$ All these suggest that contracting parties intend to have long standing legal relations set under the Svalbard Treaty.

Therefore, it is without doubt, to use evolutionary interpretation to explain the concept 'territorial waters' in the Svalbard Treaty. In Legal Consequences for States of the Continued Presence of South Africa in Namibia (South West Africa) notwithstanding Security Council Resolution 276 (1970), ${ }^{62}$ the ICJ delivered its advisory opinion that the concepts of "the strenuous conditions of the modern world" and "the well-being and development" were not invariable but changeable, so the concept was 'sacred trust. ${ }^{63}$ In the Aegean Continental Shelf case of 1978, the ICJ adopted an evolutionary interpretation of 'territorial status. ${ }^{64}$ In the Navigational Rights case of 2009, the Court held that 'commerce' should be a general concept, including both trade in goods and service, instead of a narrow concept as in $1858 .{ }^{65}$ In the same year, the WTO Appellate Body asserted that the suitable situations of using 'recording products' and 'distribution' would vary with time. ${ }^{66}$ Similarly to all the cases above,

57 I.L.C., Conclusions of the Work of the Study Group on the Fragmentation of International Law: Difficulties Arising from the Diversification and Expansion of International Law, ๆ 23 (2006), available at http://legal.un.org/ilc/texts/ instruments/english/draft\%20articles/1_9_2006.pdf(last visited on May 10, 2015).

58 Svalbard Treaty art. 1

59 Id. art. 2.

60 Id. art. 3.

61 Id. art. 2.

62 S.C. Res. 276 / U.N. Doc. S/RES/276 (Jan. 30, 1970), available at http://www.un.org/en/ga/search/view_doc. asp?symbol=S/RES/276(1970) (last visited on May 10, 2015).

63 See Legal Consequences for States of the Continued Presence of South Africa in Namibia (South West Africa) notwithstanding Security Council Resolution 276 (1970), Advisory Opinion of 21 June 1971, I 53, available at http://www.icj-cij.org/docket/files/53/5597.pdf (last visited on May 11, 2015).

64 Supra note 56.

65 See Dispute regarding Navigational and Related Rights (Costa Rica v. Nicar.), Judgment, 2009 ICJ, ๆๆ 62, 63 \& 70 (July 13), available at http://www.icj-cij.org/docket/files/133/15322.pdf (last visited on May 10, 2015).

66 See China - Measures Affecting Trading Rights and Distribution Services for Certain Publications and Audiovisual 
because the concept of 'territorial waters' in the Svalbard Treaty is developing with time, it should be also understood as consisting of not only the territorial sea set by the UNCLOS, but also costal States' sovereign areas over territorial waters. As for Svalbard, 'territorial waters' should contain a fishery protection zone and the continental shelf. Because the Svalbard Treaty should be applicable to the fishery protection zone and the continental shelf around Svalbard, other contracting parties should be entitled to non-discrimination rights in resource exploitation to these two areas.

\section{The Contracting Parties}

\section{A. Historical Analysis}

To understand the legislators' intentions of the Svalbard Treaty, it should be analyzed, through reviewing and organizing the process of concluding the Svalbard Treaty.

On June 19, 1596, Barents - a Dutch explorer - discovered Svalbard. In 17th and 18th century, Danish-Norwegian's king Christian IV claimed sovereignty over the island which was opposed by the King James I of England. Since the 19th century, Svalbard's had been regarded as terra nullius in the international community. Up until 1871, the Norwegian-Swedish plan of occupying Svalbard was abandoned because of the objection from Russia, continuing the islands ownership to be terra nullius. ${ }^{67}$ Norway appealed that it should create a new legal system to supervise and control the island based on its legal status - terra nullius - in 1907. Norway, Sweden and Russia reached a draft convention, keeping Svalbard's legal status as 'terra nullius' and supervising the island together. But the draft met a strong opposition from Germany and the US. ${ }^{6}$

In the Paris Peace Conference of 1919, Norway required research on the legal status of Svalbard to award the island's sovereignty to Norway. ${ }^{69}$ Then, Norway was asked to draw up a draft treaty on her sovereignty claim to Svalbard, giving

Entertainment Products, Report of the Appellate Body, WT/DS363 /AB/R, 21 Dec. 2009, 9 396, available at https:// www.wto.org/english/tratop_e/dispu_e/cases_e/ds363_e.htm (last visited on May 11, 2015).

67 Supra note 47 , 9 ๆ $5-8$.

68 Id. 9 ๆ 9-10.

69 R. Churchill \& G. Ulfstein, The Disputed Maritime Zones around Svalbard, Changes in the Arctic environment AND the Law of the Sea 552 (M. Nordquist, J. Moore \& T. Heidar eds. 2010). 
other countries equal rights of entering, hunting, fishing, sea transportation, industry and commerce. In addition, Sweden and the Netherlands suggested the Norwegian sovereignty of Svalbard under the mandate by national alliance, while Denmark recognized it with the Norwegian admission of the Danish sovereignty over the Greenland. Spitsbergen Commission successfully reached the agreement consistent with Norway's proposed draft treaty. On February 9, 1920, the UK, the US, Denmark, Norway, Sweden, France, Italy, the Netherlands and Japan and other 18 countries signed the Svalbard Treaty in Paris. ${ }^{70}$

The historical process of concluding the Svalbard Treaty shows that the intentions of the contracting parties are to grant Svalbard's sovereignty to Norway to strengthen management and control of the island; to push the island in a state of order; to guarantee their rights to Svalbard terra nullius; to ensure the peaceful use of the island. ${ }^{71}$ The core intentions of the contracting parties are to maintain and exercise of their own rights to the terra nullius, which were vividly reflected in the requirements of the draft to Norway given by Spitsbergen Commission and the expression of the proposed viewpoints of different countries. ${ }^{72}$

In the meantime, 'territorial waters' in the Svalbard Treaty shall include the fisheries protection zone and the continental shelf. Since the scope of application such as 'islands' and "their territorial waters" covers all areas having sovereign rights under international law when the Treaty was signed and the intentions of the contracting parties are to protect their own rights in Svalbard, the broad application scope of the Treaty is naturally intended to ensure their non-discriminatory rights which should not be restricted with the premise, giving Norway the island's sovereignty.

From another perspective, the special legal status of Svalbard - terra nullius - indicates the non-excludability of the island as that of a "semi-public goods."73 Therefore, when Svalbard was called terra nullius, the contracting parties had a semi-sovereign right for other parties. This characteristic also determines that its non-discriminatory rights shall cover all the areas permitted by international law. Considering the contracting intentions, the States should still be regarded as the 'semi sovereign' of the island. Thus, 'territorial waters' in the Svalbard Treaty shall include

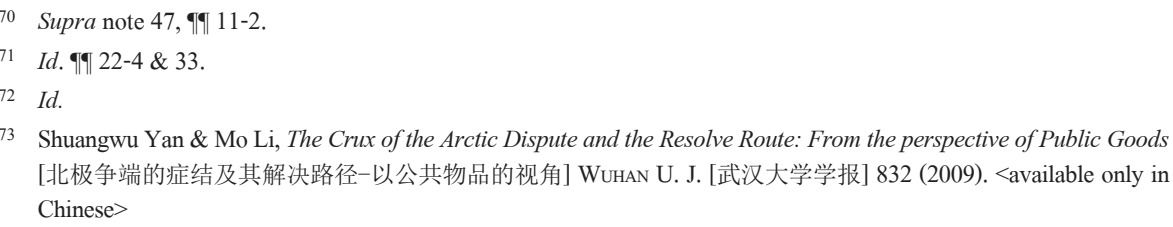

73 Shuangwu Yan \& Mo Li, The Crux of the Arctic Dispute and the Resolve Route: From the perspective of Public Goods [北极争端的症结及其解决路径-以公共物品的视角] WUHAN U. J. [武汉大学学报] 832 (2009). <available only in Chinese> 
the fisheries protection zone and the continental shelf around Svalbard.

\section{B. "Rational Contracting Parties" Analysis}

In the legal interpretation that should take the subjective and objective theory into account, Larenz refers: "If based on 'rational legislators' reasonable considerations to replace the legislators in the history, there would be no different conclusions according to the former will to interpret norms. ${ }^{74}$ That is to say, combined with the essence of the treaty, the behavioral choices made by those contracting parties should be rational from the perspective of utilitarianism and the economic analysis of law to look at contracting behavior. Applying this viewpoint to the interpretation of the treaty, it provides a second analytical method to explore intentions of the contracting parties, i.e., "rational contracting parties" analysis.

Most scholars believe that the treaty is a contract or an agreement between States. Oppenheim's International Law defines international treaties as "conventions, or contracts, between two or more States concerning various matters of interest." Article 2.1(a) of the Vienna Convention on the Law of Treaties defines 'treaty' as "an international agreement concluded between States in written form and governed by international law, whether embodied in a single instrument or in two or more related instruments and whatever its particular designation." Lauterpacht holds that:

The legal nature of private law contracts and international law treaties is essentially the same. The autonomous will of the parties is, both in contract and in treaty, the constitutive condition of a legal relation which, from the moment of its creation, becomes independent of the discretionary will of one of the parties. It is the law of the State which gives objective force to a contract in private law, and it is the rule pacta sunt servanda, one of the fundamental of international law, which imparts objective force to international treaties. ${ }^{76}$

When discussing consensus as the core element of the definition of treaty, Li Haopei, citing the view abovementioned, stressed that these 'consensus' must be intended to generate, change or abolish the mutual rights and obligations that are consistent with principles of international law. Li Haopei finally defines a treaty as follows:

Treaty is the consensuses reached by at least two subjects of international law that

74 Supra note 51, at 317.

75 H. Lauterpacht, Oppenheim's International Law 791-2 (6th ed. 1947).

76 H. Lauterpacht, Private Law Sources and Analogies of International Law 156 (1927). 
are intend to generate, change or abolish the mutual rights and obligations that are consistent with principles of international law. ${ }^{77}$

Obviously, Li Haopei's analysis on the nature of treaty contains elements of contract. In the international community, relations between sovereign States are similar to private ones in civic society where status of equality and freedom are common requirements. Therefore, autonomy will become the basic principle and the primary means of coordinating the interests or the relationship of rights and obligations between equal entities. Zhang Naigen has pointed out that:

International political relations under the regulation of international law belong to public law. The principles it applies are completely private. It means that States are regarded as 'persons' in international relations and the relationship of these persons is of equality, freedom and independence. This is the most important features of international relations. It can be said that international political relations are the civil relations with the nature of international politics. ${ }^{78}$

Based on such a judgment about the nature of the treaty, the contracting parties' intentions in the Svalbard Treaty can be judged according to the hypothesis of a rational economic man.

When the Svalbard Treaty was concluded, the intentions of the contracting parties were supposed to realize their own national interests to the uttermost, which could be observed from the nations' changes toward Svalbard, like the early competition for Svalbard's sovereignty, to the declined concern of the international community after the exhaustion of fishery resources, to the increased contradictions caused by coal development, and to the emphasis of the contracting parties' own terra nullius right. Thus, the same conclusion can be drawn with the perspective of historical analysis. The contracting parties of the Svalbard Treaty have maintained that Svalbard is legally terra nullius, but Norway should practically manage the Svalbard's environment in order to better exercise their rights. Given the high rational degree of State behavior, the contracting parties are believed to fully consider the terms, 'territorial waters,' as well as new maritime rights along the changes in international rules of coastal States. Therefore, based on intentions of the contracting parties, the term 'territorial waters' in the Svalbard Treaty shall include the fishery protection zone and the continental shelf around Svalbard.

77 Haope Li, Treaty Law [条约法概论] 1 (reprinted ed. 2003). <available only in Chinese>

78 Naigen Zhang, The Principles of International Law [国际法原理] 18 (2002). <available only in Chinese> 
So far, in the legal interpretation process of 'subjective theory,' having achieved the unification of 'historical legislator' and 'rational legislator' as addressed by Larenz, the following conclusions can be drawn:

From the perspective of the 'subjective theory' to explore the contracting parties' intentions, the term 'territorial waters' in the Svalbard Treaty shall include the fishery protection zone and the continental shelf around Svalbard, that is to say, the application of the Svalbard Treaty shall consist of these two areas.

\section{Conclusion}

Larenz discussed the target of legal interpretation in Methodenlehre der Rechtswissenschaft:

The law is the original creator - attempt to create full or partial regularity - the concrete will, which consists of both the 'subjective' ideas and will target, but also includes - legislators cannot (all) know - the 'objective' target and inevitable requirements of things. If you want to fully understand the law, you have to simultaneously achieve both. $^{79}$

As previously described, treaty interpretation should take both normative legal significance of the treaty terms and the contracting parties' intentions into account. Only in this way, the interpretation can be consistent, reasonable and fair in consonance with the purpose of the treaty established.

Under the guidance of this idea and through 'objective theory' and 'subjective theory,' this article has explored the meaning of the term 'territorial waters' in the Svalbard Treaty from the perspective of treaty interpretation. With the method of evolutionary interpretation, historical analysis and "rational contracting parties" analysis, it is comprehensively concluded that the Svalbard Treaty is applicable to the fishery protection zone (and to the possible EEZ if Norway decides to establish one) and the continental shelf in Svalbard, thus other contracting parties are entitled to non-discrimination rights in resource exploitation to these two areas.

This conclusion has an important significance for China. Due to the geographical location, funding, technology level and sailing and many other limited factors,

79 Supra note 51, at 318. 
participation in the Arctic affairs for China is still a difficult project. Recently, China's main activity carried out in the Arctic is limited only to scientific investigation. Mineral resources development and waterway utilization are still beyond China's ability. But this does not mean that the Arctic area is insignificant to China. On the contrary, China is paying much attention to rich mineral resources and strategic importance of the Arctic area. The conclusion (The Svalbard Treaty is applicable to the fishery protection zone and the continental shelf around Svalbard) means that China, as a contracting party of the Svalbard Treaty, is entitled to enjoy nondiscrimination rights conferred by the treaty in these two areas. In line with China's intentions, her rights in Svalbard and the nature of its evolution should be confirmed. Meanwhile, it is conducive for China to strengthen the connection with Arctic affairs, providing for a more solid legal foundation to be more deeply involved in Arctic affairs and thus fully express interest demands. 